\title{
Karstification in the mountains Durmitor (Montenegro) and Pirin (Bulgaria) and its expression in surface landforms
}

\author{
Emil Gachev, Ilia Mitkov \\ South-west University "Neofit Rilski” \\ Blagoevgrad, Bulgaria
}

\begin{abstract}
The present study makes a comparison of the development of karstic processes and their landform expression in two representative high mountain areas on the Balkan Peninsula: Durmitor (Dinaric chain, Montenegro) and Pirin (Rhodope massif, Bulgaria). Main accent is put on epikarst and its features. On the background of many similarities: strong glaciation in the Pleistocene, pronounced cirques and arêtes, preserved moraine deposits, rough present-day topography, some obvious differences are observed. These are mostly derived by the differences in carbonate bedrock (limestone in Durmitor and marble in Pirin), and climate (damp to the west and drier to the east). The tectonic setting is also important. Such a comparison has not been done so far. It would contribute to obtain a better regional outlook on the processes in the high mountain karstic areas in Southeastern Europe.
\end{abstract}

Keywords - high mountain karst; Northern Pirin; Balkan Peninsula

\section{INTRODUCTION}

Karst processes generate a distinct type of environment, which is clearly distinguishable on the field. Apart from their high aesthetic attractiveness, karst areas are important for the formation of water resources and biodiversity. In South-eastern Europe, and in particular on the Balkan Peninsula, karst is wide spread (here is the homeland of classical Dinaric karst which has given the name to the whole variety of processes related to water dissolution of rocks).When speaking of high mountain karst however, we should admit that such areas provide some of the most spectacular landscapes in our region. If the term 'high mountain karst' is restricted to areas higher than $2000 \mathrm{~m}$ a. s. l., its distribution on the Balkan Peninsula will be much more limited. Two main areas can be outlined for this type of karst: Dinaric area to the west, with karst mainly in limestone, and Rhodope area to the east, predominantly in marbles (Fig. 1). Except in bedrock, the two areas differ considerably also in climatic conditions, the climate to the east being much drier. The high mountain karst areas selected for the present study: Durmitor and Pirin, are among the most representative for these areas.

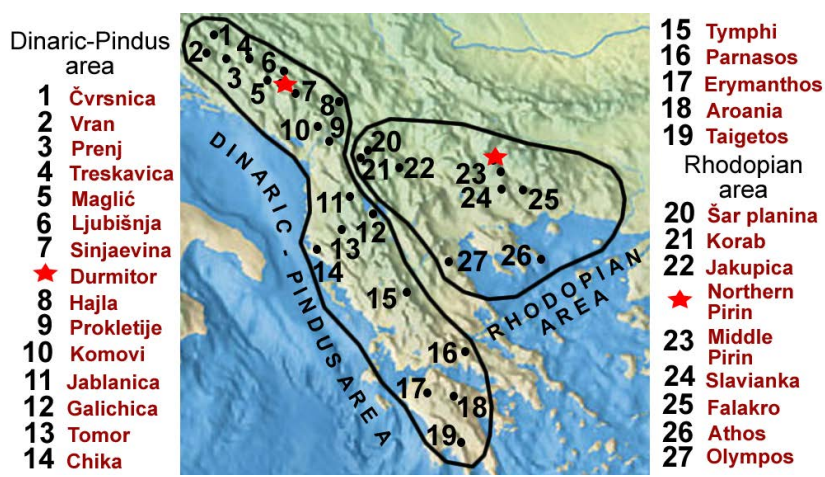

Fig. 1. Areas with high mountain karst on the Balkan Peninsula, and sites ofthe study.

\section{STUDY SITES}

\section{A. Geographical location}

Durmitor is situated in northwest Montenegro. This is the second highest massif in the Dinaric chain (after Prokletije in northern Albania), part of the central range, reaching to $2522 \mathrm{~m}$ (Bobotovkuk peak). This mountain is small, but sharply distinct: it rises abruptly over $1000 \mathrm{~m}$ above surrounding plateau surface at $1400-1600 \mathrm{~m}$ a. s. 1 . Nearby are the deepest gorges of Europe: Tara canyon to the north (depth down to $1340 \mathrm{~m}$ ), and Piva canyon to the west $(1100 \mathrm{~m})$ [1]. The main ridge of the mountain forms an arc opened to NE, with altitudes between 2300 and 2450 m. a. s. 1 .

Pirin lies in Southwest Bulgaria, in the central area of the vast Rhodope massif. This is the third highest mountain on the Balkan Peninsula (after Rila and Olympus), with the peak Vihren at $2914 \mathrm{~m}$ a. s. l. The mountain is much larger than Durmitor. It has generally a rhomboid shape, to the west and east it is framed by the deep valleys of Struma and Mesta rivers. Low passes separate it from its mountain neighbours Rila (2925 m to the north) and Slavianka (2212 $\mathrm{m}$, to the south).

\section{B. Geology}

The northern and central parts of Durmitor are made of thick Jurassic limestone. To the south cretaceous flysch formations are napped over the limestone, the nape line 
passing right on the southern slope of the subparallel main ridge. This is a factor for increasing the landform diversity of the mountain. Pirin is a horst structure of three Mesozoic granite intrusions, surrounded by a mantle of metamorphic rocks, which determine great diversity of landscape. Marbles compose parts of Northern Pirin (Vihren area, the highest section of the whole mountain). They are very thick and well stratified, with layers submerging towards NE. There are marbles also in Central Pirin, but altitude there barely reaches $2000 \mathrm{~m}$. a. s. 1 . Uniformity of marble rocks determine lower rate of landform diversity within the karst complex in Pirin compared to Durmitor.

\section{Relief}

The highest areas of both mountains have been shaped by the combination of glacial, periglacial and karst processes. They were heavily glaciated during the Pleistocene, but during the maximum glaciation the depression of the Equilibrium line altitude was greater in Durmitor (950-1000 m below the highest peaks, according to [2]) than in Northern Pirin (about 650-700 m [3]). In result, several deep cirques were carved on the northern side of both mountains, some of them also quite large. Exaration had much smaller effects on southern slopes. Today high mountain areas are dominated by periglacial processes and karstification, the latter being strongest over cirque bottoms, which are turned into labyrinths of sinkholes, small ridges and numerous caves.

\section{Climate}

Climate on both sites combines Mediterranean and temperate influences, which reflect their position close to the sea, but not adjacent to it. Being among the highest, these mountains are opened simultaneously to the south and to the north, to feel the climatic impacts of the Mediterranean and mainland Europe. Temperatures in both mountains are similar at same altitudes, maybe somewhat lower in Durmitor due to its more northern location. Temperatures have been gradually rising in the last decades [3, 4]. Precipitation regime in both areas is similar. Two maxima, in November-December and May-June, reflect the influences from NW (Atlantic cyclones) and SW (Mediterranean cyclones). Winter maximum is however stronger, and if the year is divided into two, it will appear that about $2 / 3$ of precipitation falls in the cold half of it, mainly as snow for the altitudes above $2200 \mathrm{~m}$. The studied locations differ most in the total amount of precipitation. The annual sum in Durmitor is 2.5 times higher than that in Pirin (2500-2600 mm vs $1000-1100$ $\mathrm{mm})$ [5].

\section{COMPARISON OF SURFACE KARST LANDFORMS BETWEEN DURMITOR AND PIRIN}

Surface landforms in Durmitor are representative for the Dinaric karst. Here cirque bottoms, and also low slopes, are deeply karstified. Corrosion has produced very rough topography, but the surfaces of the numerous hills and sinkholes are smooth and rounded. Line rill corrosion microforms cover steep rock faces. These are narrow channels with a width in order of 2-10 cm and depth 5-15 $\mathrm{cm}$, which run vertically, parallel to each other. Surface karst processes also have strong influence on mountain summit surfaces, which are flat in the eastern section of the mountain (Šlijeme plateau). Large and deep sinkholes can be found there, the most spectacular being "The snowy sinkhole" (Snežna vrtača). Stone arches and small canyons enrich the topography of the plateau. Physical (frost) weathering is more active on steep slopes and in couloirs (due to the greater gravitation instability of rocks) and in shaded locations, where temperatures cross $0^{\circ} \mathrm{C}$ most of the days of the year. Physical destruction of limestone produces extensive screes and colluvial fans with debris mainly of pebble size.

Compared to Durmitor, environment in the karstic areas of Northern Pirin possesses some characteristics that implies on a similarity to the periglacial landscape in silicate rocks. For example, although carbonate in composition, marble is at the same time a crystalline rock. It has strata like limestone, but disintegrates to larger blocks like granite or gneiss. Therefore, the screes formed have a prevalence of larger sized debris. Such accumulations allow for cold air and water to penetrate and store inside, and even freeze there and produce bulges of a rock glacier type. Inside cirques, epikarst features are present, but they are not so pronounced as in Durmitor, neither on the bottom, nor along slopes. There are two reasons for this: first, the much lesser amount of precipitation, and second, the higher altitude of cirques in Pirin, which resulted from the $600 \mathrm{~m}$ higher level of ELA during the coldest phases of the Pleistocene. Higher elevation means lower temperature, which increase the percentage of snow precipitation and enhances frost weathering. In the marble cirques of Northern Pirin karstification prevails only within the sinkholes in the deepest part of cirque bottoms where snow retains for 7-8 months a year. Main karstification agent is snow melt water. Predominance of karstification over frost action at these sites is indicated by the rounded shape of large stone blocks, with recesses in a crossed pattern that follow the crystalline type cracks in marble. Parallel microforms are not formed on slopes due to small rainfall amounts. Both on slopes and ridges frost action prevails over corrosion, and this is enhanced in the highest slopes and ridges with altitude above $2800 \mathrm{~m}$ a. s. l. There, due to the extreme rates of frost action, bedrock is stirred on small loose blocks, resembling "halva” dessert (a landscape untypical for Durmitor). Both sites have similarities in bare rock faces, which surfaces are tall and smooth, in the abundance of couloirs, and the general topography of macroforms cirques and ridges.

\section{GLACIOKARST FEATURES OF SPECIAL INTEREST}

Current presence of small glaciers is by no doubt something that Durmitor and Pirin have in common. Two glacierets are situated in the high cirques of Northern Pirin: Snezhnika glacieret (2400-2450 m a. s. 1., $0.6 \mathrm{ha}$ ) under the NE wall of Vihren peak, and Banski suhodol (2610-2700 $\mathrm{m}, 1.1$ ha) below the second highest summit in Pirin, Kutelo (2908 m) [5]. These are the southernmost glacial masses in Europe at present [6]. Debelinamet (2.5 ha) is the only small glacier in Durmitor [7]. Much higher precipitation in the Dinarides allow for the glacier to persist at surprisingly low altitudes (2035-2200 m a. s. 1.). Small glaciers that exist at present on the Balkans are in fact products of karstification. In such thermal conditions (annual air temperatures $+1^{\circ} \mathrm{C}$ and above) they would not exist away from the light colored carbonate bedrock, and its surface karst, which provides for instant drainage of 
melt waters, keeps firn/ice masses relatively cool and dry during ablation season, and hinders rapid melting. Therefore, small glaciers in Pirin and Durmitor can be considered specific elements of high mountain epikarst environment.

Also specific for Durmitor are several small lakes, which formation should be addressed to the existence of tiny layers of other rocks between the limestone strata. In Pirin, there are some lakes in areas bordering the marble (e. g. Sinanishkoezero), but not within the karst area.

\section{Conclusions}

High mountain karst in Durmitor and Pirin have lots of similarities and some differences, but the former prevail over the latter. These are specific environments with alpine character of relief, rough topography, lack of surface running waters, but presence of perennial snow and ice. Mainly due to the much higher precipitation amounts, karstification in Durmitor is more intense and plays a bigger role in the formation of high mountain relief. On the contrary, the crystalline character of marble and the colder conditions, resulting from the higher altitude, determine the prevailing share of physical weathering (frost heave) in the formation of morphosculpture in the highest areas of the karstic part of Pirin. Chemical denudation there is stronger only in deep depressions.

\section{REFERENCES}

[1] B. Cerović, Durmitor i kanjon Tare.Vodič. Beograd, 1991. (in Serbian)

[2] P. Djurović, "Reconstruction of the Pleistocene glaciers on Mount Durmitor in Montenegro”, Acta Geographica Slovenica, vol. 49, no. 2, pp. 263-289, 2009.

[3] V. Popov, Pirinplanina s dolinatana Mesta. Geography of Bulgaria, vol.1, 1966. (in Bulgarian)

[4] P. Djurović, Visokoplaninskikras Durmitora. Beograd, 2011. (in Serbian)

[5] P. Nojarov, "Modeling of climate changes in Rila and their impact on Seven Rila lakes", in Eighth Scientific Conference Space, ecology, safety, Sofia, 4-6 Dec. 2012, pp. 391-401.

[6] E. Gachev, K. Stoyanov, and A. Gikov, "Small glaciers on the Balkan Peninsula: state and changes in the last several years", Quaternary International, vol. 415, pp. 33-54, 2016.

[7] K. Grunewald and J. Scheitchauer, "Europe's southernmost glaciers: response and adaptation to climate change”, Glaciology, vol. 56, pp. 129-142, 2010.

[8] P. Djurović, "The Debelinamet glacier from the second half of the 20th century to present”, Acta Geographica Slovenica, vol. 52, no. 2, pp. 277-301, 2012.
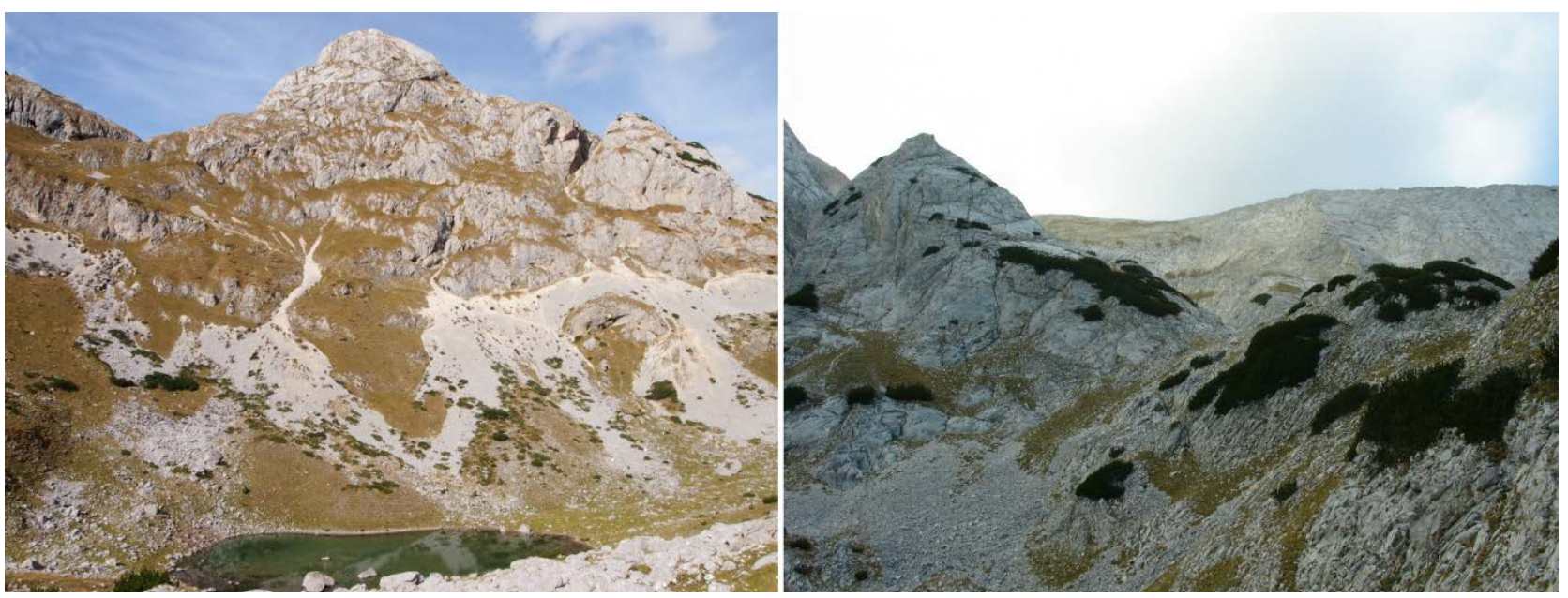

Fig. 2. Typical epikarst features in Durmitor (left): corroded slopes, pebble-grain screes and a lake; and Pirin (right): boulder-size screes and slopes with weaker karstification and higher physical weathering. 